\title{
Volcanic reservoirs: historic and current context
}

\author{
Patricia Lopes Menezes DESCOVI'T, Marcus Vinícius Berao ADE², \\ Gabriela de Oliveira AVELLAR² , Silvia Lorena Bejarano BERMÚDEZ1 \& \\ Fábio Pinto VIEIRA?
}

\begin{abstract}
${ }^{1}$ National Observatory, Department of Geophysics. General José Cristino Street, 77, Rio de Janeiro, Brazil (patriciadescovi@on.br, fabiovieira@on.br, silviabermudez@on.br).

${ }^{2}$ University of State of Rio de Janeiro, Faculty of Geology, Department of Stratigraphy and Paleontology. São Francisco Xavier Street, 524, 2020A room, Maracanã, 20550-013, Rio de Janeiro, Brazil (gabi.oavellar@gmail.com, marcusade326@gmail.com).
\end{abstract}

\begin{abstract}
Within the oil and gas industry, igneous rocks are still seen as exploration and production challenges, due to their diverse petrogenesis and the wide range of values of some important petrophysical properties. This petrophysical variability depends on both primary and secondary processes. These facts made these rocks unattractive for decades. This condition is still observed in many fields around the world. This article has as main objective to make a historical review of studies developed globally with a focus on igneous rocks that act as a reservoir in petroleum systems. The review covered in this article was developed from a compilation of global data, thus allowing an overview of the countries that produce hydrocarbons in volcanic rocks, what types of rocks, geological age, and size of the reserve. Countries such as China and Indonesia stand out with higher daily production, exceeding orders of quantities of $10^{8}$ cubic meters of gas and $10^{4}$ tons of barrels of oil. In these countries, geological patterns are already being noticed in volcanic reservoirs, such as more recent geological ages and typical lithologies. Also, this work seeks to emphasize the importance of studying this type of reservoir, as its knowledge can lead to the solution of real problems within the world oil and gas industry.
\end{abstract}

Keywords. volcanic reservoir, volcanic hydrocarbon accumulation, unconventional resources, igneous rocks, atypical petroleum system.

Resumo. RESERVATÓRIOS VULCÂNICOS: HISTÓRICO E CONTEXTO ATUAL. Na indústria do petróleo e do gás, as rochas ígneas ainda são vistas como desafios de exploração e produção, devido à sua diversificada petrogênese e pela ampla escala de valores de algumas propriedades petrofísicas importantes. Esta variabilidade petrofísica depende tanto de processos primários como secundários. Tais fatos tornaram estas rochas, por décadas, pouco atrativas. Esta condição ainda é observada em muitos campos em todo o mundo. Este artigo tem como principal objetivo fazer uma revisão histórica dos estudos desenvolvidos a nível mundial com enfoque nas rochas ígneas que atuam como reservatório em sistemas petrolíferos. A revisão abrangida neste artigo foi desenvolvida a partir de uma compilação de dados globais, permitindo assim uma visão global dos países que produzem hidrocarbonetos em rochas vulcânicas, quais tipos de rochas, idade geológica e tamanho da reserva. Países como a China e a Indonésia destacam-se com uma produção diária mais elevada, excedendo encomendas de $10^{8}$ metros cúbicos de gás e $10^{4}$ toneladas de barris de petróleo. Nesses países, padrões geológicos já vêm sendo percebidos em reservatórios vulcânicos, como idades geológicas mais recentes e litologias típicas. Além disso, este trabalho procura enfatizar a importância do estudo deste tipo de reservatório, pois o seu conhecimento pode levar à solução de problemas reais dentro da indústria mundial de petróleo e gás.

Palavras-chave. Reservatórios vulcânicos, reservatórios, acumulação de hidrocarbonetos em vulcânicas, recursos não-convencionais, rochas ígneas, sistemas petrolíferos atípicos. 


\section{Introduction}

Volcanic rocks have been known as hydrocarbon reservoirs for more than 130 years, they have been accidentally discovered by explorations in other lithologies (Schutter, 2003; Farooqui et al., 2009; Ran et al., 2014). The practice of drilling through igneous rocks has gained attention in several branches of industry, not only for the identification of hydrocarbons, but also for uses in geothermal energy (Fridleifsson \& Elders, 2005), sequestration of carbon dioxide and water resources in crystalline rocks (Zakharova et al., 2012).

Schön (2015) reports that, globally, approximately $60 \%$ of petroleum reservoir systems are carbonate, $37 \%$ sandstone, $1 \%$ are volcanic and $2 \%$ other lithologies. Despite the smaller percentage, volcanic rocks are common in sedimentary basins and, therefore, these rocks must be better studied. Igneous rocks, in general, may represent an unconventional reservoir, in addition to being able to assume other functions within the petroleum system, such as sealing, trapping, and facilitating maturation by providing a catalyst and thermal energy (Conceição et al, 1993; Neumann et al., 2003; Eiras \& Wanderley Filho, 2003).

To better understand these rocks, it is necessary to characterize their seismofacies (Delpino \& Bermúdez, 2009; Angkasa et al, 2017; Infante-Paez \& Marfurt, 2018, Planke et al., 2018), identify the igneous zones in well logs (Planke et al., 1994; Penna et al., 2018; Oliveira et al., 2019; Fornero et al., 2019; Correia et al., 2019), its petrogenesis, and petrophysical properties (Greenfield et al., 2019; Jerram et al., 2019). According to Jiang et al. (2010), the petrophysical variability of igneous rocks is a key point to define a good reservoir and it can be influenced by cooling fractures, presence of vesicles and breccias, alteration, and fractures after solidification (Sruoga \& Rubinstein, 2007; Zou, 2017; Yao et al. 2020).

This variability reflects different responses observed by geophysical methods which will be approached in the next topics of this article. The main objective here is to make a historical review, from the first identifications of oil and gas in igneous rocks, in 1887, of studies developed globally with a focus on igneous rocks that act as a reservoir in petroleum systems, allowing an overview of the countries that produce hydrocarbons in these rocks. The review covered in this article was developed from a compilation of global data, which is an update of the dataset, preliminarily presented by Schutter (2003) and Petford \& McCaffrey (2003).

\section{Historical}

The first documented studies of hydrocarbons in volcanic rocks were in 1887, in the San Joaquim Basin, California (United States) and in 1900, in the Hara field (Japan) (Zou, 2013). Later, in 1918, in the Panhandle-Hugoton field (United States), 1,360,000 thousand barrels of oil (Mbbl) and 2,093 billion $\mathrm{m}^{3}$ of gas were discovered (Rauzi, 2001). But, the first successful case in the world of exploration aimed at igneous rocks was in 1923, in the granite reservoir of La Paz field (Venezuela), total reserves of $330,000 \mathrm{Mbbl}$ were calculated, from which up to $55,000 \mathrm{Mbbl}$ have been recovered until 1944 when production started to decline (Koning, 2014).

In 1953, with a well drilling on the "economic basement", in Venezuela, reserves in the order of $325,000 \mathrm{Mbbl}$ of recoverable reserves were discovered at fracture granite (Landes et al., 1960; Koning, 2014). The same year that Colombia made discoveries in this type of reservoir (Sharipov et al., 2018). The economic basement is defined, according to Duarte (1997), as the depth below which there is no economic interest for oil and gas exploration and production. For the hydrocarbon to accumulate, it is necessary that they are fractured and/or altered, and that the generating rock may be in any stratigraphic position, in addition to needing a trap and seal (Koning, 2014).

After this success, the exploration of hydrocarbons in igneous rocks begins in a systematic way in Asia, in magmatic rocks of different ages. Examples are oil reservoirs in rhyolites in Japan; granites in Vietnam; tuffs in Georgia; andesites, basalts and porphyry in Azerbaijan; and andesites in Indonesia (Cuong \& Warren, 2009; Zou, 2013). In 1957, major 
gas discoveries were made in China by the oil company PetroChina in the Songliao and Junggar basins. However, even with great potential, the gas contained in the volcanic rocks was not immediately exploited due to the complexity of these types of reservoirs. Only in 2004, when there was a partnership between the companies PetroChina and Schlumberger, from a better understanding and characterization of this reservoir, the exploration of this discovery became viable. Currently, the Songliao and Junggar basins hold reserves of 1 trillion $\mathrm{m}^{3}$ of gas and together have the largest igneous reservoirs in the world (Farooqui et al., 2009). Only the Daqing field, in Songliao, has reserves equivalent to 1.6 billion $\mathrm{m}^{3}$ of gas, in intercalations of sedimentary and volcanic layers (Zou, 2013).

Other countries made discoveries in the next decades, such as the giant Japanese fields discovered in 1968 (Niigata) and 1978 (Nagaoka South). As well as occurrences in the Barmer and Cambay basins, in western India. The Cambay Basin shelters basalts flow interbedded with lake sediments, shales, sandstones, and estuarine carbonates (Ran et al., 2014). The West Java (Indonesia) and its reserves in volcanic tuffs, which comprise about 635 million $\mathrm{m}^{3}$ of oil $(4,000,000$ $\mathrm{Mbbl}$ ) and 85 million $\mathrm{m}^{3}$ of gas (Bishop, 2009). In the 1980 and 1990s, important discoveries were made in fields in Egypt at Zeit Bay (597,000 Mbbl), Vietnam in Bach Ho (1,380,000 Mbbl) (Sharipov et al., 2018) and India at Mumbai High (Patil et al., 2018). In China, new reserves were discovered in the paleogenic diabases of the Jizhong depression, in the basalts of the Sichuan Basin, in the Junggar Basin, respectively in 1985, 1992, and 1993 (Ran et al., 2014).

The 21st century is the watershed of the development of volcanic rocks as reservoirs. Previously, systematic research, theories and technologies were scarce. The authors propose some basic stages of world developments (Ran et al., 2018): 1) Refutation stage - period preceding 1950, when magmatic rocks were considered incompatible with petroleum resources, according to conventional resources based on geology; 2) Discovery stage - period between 1950 and 1960, when volcanic reservoirs are discovered accidentally and are considered a potential and, therefore, exploration targets; 3) Exploratory stage - period from 1970 to the end of the 20th century, when several volcanic reservoirs are identified, explored, and developed, even if superficially. This phase involves fieldwork in outcrops, analytical studies of types of facies and volcanic rocks, the establishment of evaluation methods, in addition to laboratory studies and developmental performances; 4) Growth stage a phase that begins with the 21st century, where systematic research and techniques are applied, mainly in fields in China.

This last stage is the current context of some countries that already have the application of solid methodologies in their workflows and which will be better detailed in the next topic.

\section{Current global context}

Large investments in research to discover potential fields have been made in some countries. In Argentina, petrophysical and geochemical analysis (Sruoga \& Rubinstein, 2007) have been used to study the quality of potential reservoirs and improvements in the quality of 3D seismic data applied to the detection of fractured intrusive bodies (Delpino \& Bermúdez, 2009; Spacapan et al., 2020), beyond the application of seismic modelling for better accuracy in seismic interpretations (Rabbel et al., 2018). In Mexico, the extraction of attributes is practical for the study of seismofacies and the behaviour of igneous rocks in well logs, in addition to the use of petrophysics and petrology for a better definition of volcanic reservoirs (Lenhardt \& Götz, 2011; Sarkar et al., 2017).

In Australia, igneous rocks have been reconsidered in prospects where they were previously ignored (Holford et al., 2017; Zahedi \& MacDonald, 2018; Bischoff, 2019). In New Zealand, pores and fractures have been identified in studies of physical volcanology in cores (Kennedy et al., 2017), reanalysis of ancient magmatic systems with reflection seismic (Bishoff, 2019), application of neural networks in 3D seismic data (Kumar et al., 2019) and study of seismic expressions of igneous rocks (InfantePaez \& Marfurt, 2018).

In Indonesia, accumulations of 
hydrocarbons have been observed in volcaniclastic rocks, based on image profiles and calculations of total organic carbon (TOC), have allowed the development of new concepts of plays in oil systems (Seubert, 2015). In Vietnam, Tan et al. (2016) applied processing techniques and seismic attributes to improve the imaging of fractured basements. In India, characterization studies of reservoirs using petrophysics, special logs, such as Nuclear Magnetic Resonance (NMR) and chromatography are carried out, as well as the application of advanced mathematics with tests of effectiveness, geostatistics and integration of different physical parameters (Chowdhury et al., 2014; Mund et al., 2017). China has been using the combination of NMR data, microresistance image profiles, conventional logs and mudlogging, in addition to the traditional use of seismic, well logs and petrophysics (Wang \& Chen, 2015; Wang et al., 2018; Hu et al., 2019; Sun et al., 2019).

The development of new methodologies and technologies has allowed advances in the identification and exploration of volcanic petroleum systems (Ran et al., 2018). This leads us to think about the importance of studying them, especially in countries that still consider igneous rocks a problem and not a new option for the industry. For decades, many countries, such as China and Norway, have been developing methodologies that have made it possible to identify new reserves and observe standard characteristics in these reservoirs (Liu et al., 2013; Wang et al., 2018; Jerram et al., 2019; Quirie et al., 2018).

\section{Classifications of volcanic reservoirs}

A few classifications have been applied to characterize volcanic reservoirs. One of the most known was proposed by Zou (2013), as shown in table 1. Each type of reservoir can vary according to their occurrence, type of pores, geometries, porosity, and permeability.

In lava-type reservoirs, it is usual for the porosity to be primary, and formed predominantly by vesicles and cooling fractures (Fig. 1). However, as Seubert (2015) recalls, they can be affected secondary by alteration, transport, and accumulation, resulting in tuffs, ignimbrites, ashes and hyaloclastites.

Other classifications, such as the one developed by Delpino \&Bermúdez (2009), consider the hydrocarbon systems affected by intrusions, characterizing them according to which element was intruded. Type I considers those in which the igneous rocks intrude the source rocks. Type II, includes cases in which intrusions occur in other elements of the petroleum system.

Table 1. Genesis and types of volcanic reservoirs. Modified from Zou (2013).

Tabela 1. Gênese e tipos de reservatórios vulcânicos. Modificado de Zou (2013).

\begin{tabular}{ccccc}
\hline Control Action & Reservoir Space & Reservoir Type & Distribution and attitude & $\begin{array}{c}\text { Reservoir } \\
\text { Category }\end{array}$ \\
\hline Volcanism & Primary & $\begin{array}{c}\text { Lavas, intrusive and } \\
\text { volcanoclastic }\end{array}$ & $\begin{array}{c}\text { Stratified effusive/eruptive facies; } \\
\text { shallow tabular intrusive facies; } \\
\text { exposed stacked and ringed facies }\end{array}$ & $\begin{array}{c}\text { Lava, } \\
\text { volcaniclastic } \\
\text { and sills }\end{array}$ \\
\hline Diagenesis & Secondary & Weathered & $\begin{array}{c}\text { Shallow (<300 meters) and deep } \\
\text { (corrosion of acidic fluids, altered } \\
\text { areas, sills and stocks) }\end{array}$ & $\begin{array}{c}\text { Dissolved or } \\
\text { fractured type }\end{array}$ \\
\hline Tectonism & Fracture & Fractured & High structural and fractured zone & - \\
\hline
\end{tabular}


There is another, less usual classification, proposed by Ran et al. (2014), which subdivides volcanic rocks into two groups: reservoir and non-reservoir. The first group includes rocks with porosity resulting from vesicles, intergranular or dissolved pores and cooling fractures, while the second one includes volcano-sedimentary rocks and tight reservoirs.

\section{Data sources and global distribution}

A global summary of oil and gas reserves in igneous rocks was previously carried out by Schutter (2003) and reviewed by Petford \& McCaffrey (2003), where more than 300 occurrences (169 measured reserves) in 39 countries were recorded. We updated this count and observed that, currently, these occurrences can reach 400 locations distributed in more than 54 countries, as shown in the new distribution map in figure 2. Some occurrences are not yet disclosed and/or published.

These rocks act not only as reservoirs, but they can also influence all levels of the petroleum system, act as a seal, trap or they may enable maturation of source rock (Conceição et al., 1993; Jerram, 2015). The database was composed by the compilation of studies, such as Powers (1932), Schutter (2003), Petford \& McCaffrey (2003) and Liu et al. (2013), in addition to the more recent data. All of them are available in supplementary material, sorted by country.
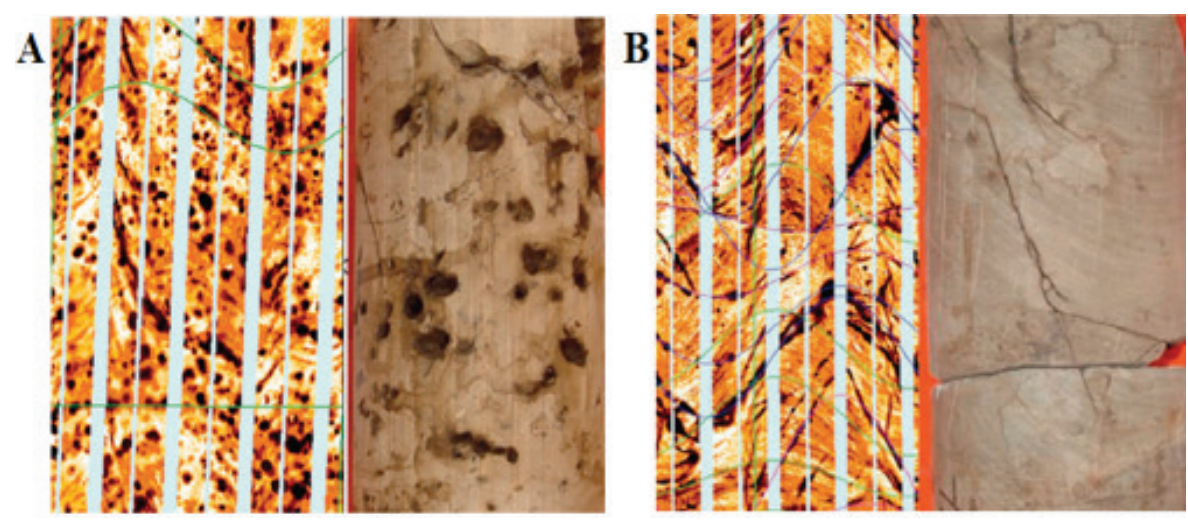

Figure 1. Examples of pores, cavities, and fractures in volcanic rocks. A) original pore (rhyolite); B) structural fracture (rhyolite).

Figura 1. Exemplos de poros, cavidades e fraturas em rochas vulcânicas. A) poro original (riolito); B) fratura estrutural (riolito).

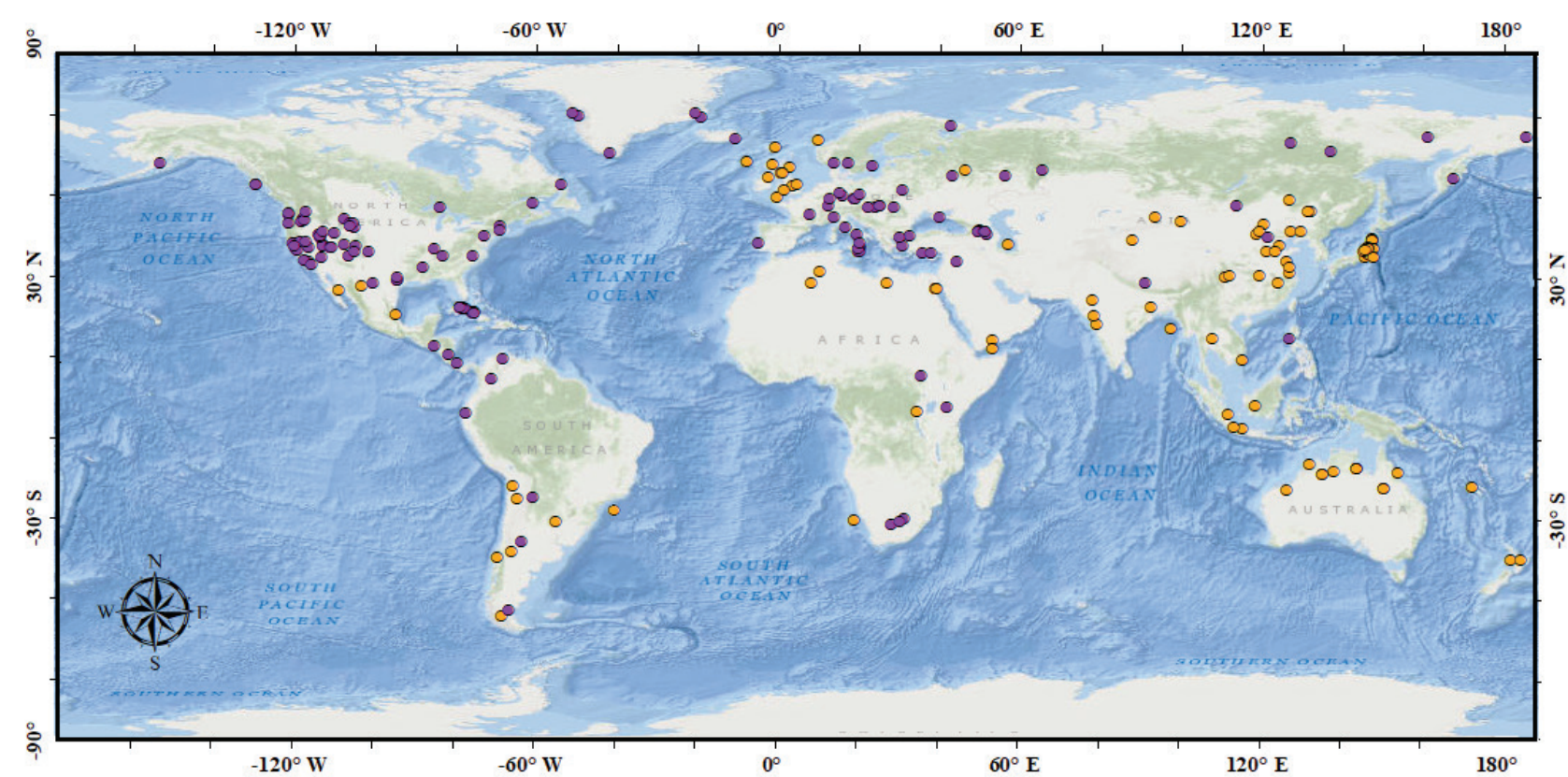

Figure 2. Global distribution of hydrocarbon occurrences associated with igneous activities or rocks. In orange old data and in purple new data.

Figura 2. Distribuição global de ocorrências de hidrocarbonetos associados com atividades ígneas ou rochas. Dados antigos em laranja e dados novos em lilás. 
In the fractured basement alone, there are 126 production fields spread across 24 countries (Trice et al., 2019). In this type of igneous reservoir, the biggest highlight was in the Bach Ho field in Vietnam, discovered in 1975 in the offshore Cuu Long Basin. The field produced oil from Cretaceous and Triassic granodioritic and granitic rocks overlaid by Oligocene lake shales, and production was estimated in 2,000,000 Mbbl with flow rates of 14,000 barrels of oil per day (BOPD) (Tan et al., 2016). More recent discoveries from the Shetlands platform, the Lancaster and Whirlwind fields, in the United Kingdom, have a potential of 3,000,000 Mbbl (Trice et al., 2019) and the La Paz field, in Venezuela, with an average production of 3,600 BOPD in granites (Koning, 2014) also represent a good example of volcanic reservoirs.

The largest reserve size of hydrocarbons in igneous reservoirs was raised too by Schutter (2003) and Petford \& McCaffrey (2003). We updated this data and obtained a total of 78 locations, which is equivalent to an increase of 26 large accumulations, according to the diagram on figure 3.

\section{Reserve Size (Mbbl)}

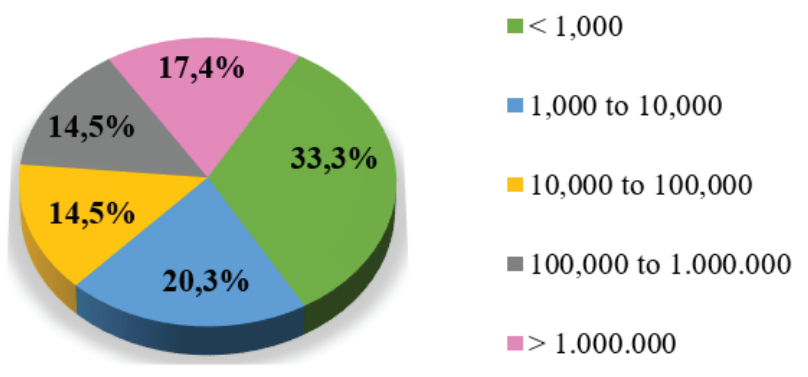

Figure 3. Classification of global reserves in igneous rocks. The size in Mbbl.

Figura 3. Classificação de reservas globais em rochas ígneas. Tamanho em Mbbl.

The map in figure 4 shows the distribution of the locations with large hydrocarbon reserves in volcanic reservoirs, that is, reserve sizes that have at least $1,000 \mathrm{Mbbl}$ (supplementary material).

Based on these reserve data, it is also possible to observe that there is a difference between occurrences that are considered as commercial and non-commercial reserves nowadays (Fig. 5). As there is little information disclosed regarding the production of oil and gas in igneous rocks, most of these reserves are still non-commercial, equivalent to $50.2 \%$, against $33.5 \%$ of reserves in commercial production and $16.3 \%$ are fields with no reserve or unpublished data.

More quantitative details about some largest fields with hydrocarbon production in igneous rocks by country are present in chart 1 , according to Xiaohong (2016). These are located in China and comprise extrusive rocks from Kellamelli $\left(1,053.10^{8} \mathrm{~m}^{3}\right.$ of gas) and Xushen fields and Changshen $\left(2,990.10^{8} \mathrm{~m}^{3}\right.$ of gas).

\section{Geological and geophysical settings}

\section{1 Geological aspects}

Igneous rocks do not generate oil or gas, however, its characteristics can be decisive for trapping fluids or increasing hydrocarbon generation. This is directly related to its form of generation, cooling and possible secondary changes that may occur (Liu et al., 2013). The chemistry of the magma (e.g. acid, intermediate or basic), the environment in which it has cooled (e.g. subaerous, subaqueous or subsurface), the energy involved (strong or weak) and whether it has been recurrent are determining factors to understand what roles igneous rocks can play. The results of these interactions directly influence the geophysical responses and the reservoir's petrophysical properties, such as porosity and permeability (Petford \& McCaffrey, 2003). The quality of the reservoir also depends on elements such as silica content (magma viscosity), cooling rate, the occurrence of vesicles and vugs, volatile content and tectonism (Couves, 2015). Igneous rocks, therefore, are synonymous of heterogeneity. To better understand such elements, there is a consensus among several researchers about the importance of seeking to improve our understanding on volcanic facies (e.g. Nelson et al., 2009; Jerram et al., 2009; Jerram, 2015; Millett et al., 2016; Rossetti et al., 2019). 


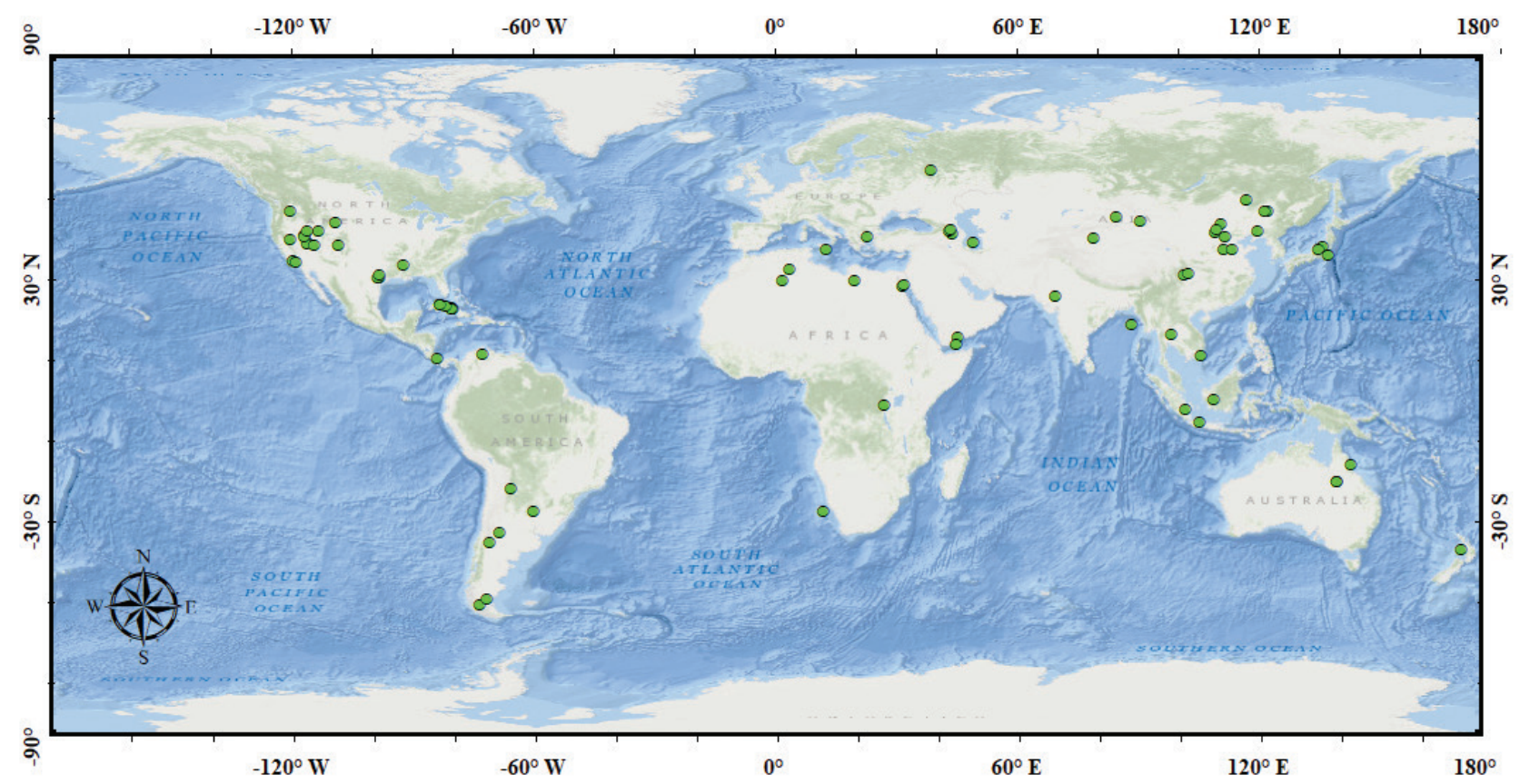

Figure 4. Location of the 78 largest reserves knows in volcanic reservoirs (circles in green).

Figura 4. Localização das 78 grandes reservas conhecidas em rochas vulcânicas (círculos em verde).

Volcanic reservoirs are more frequent in Mesozoic and Cenozoic periods (Zou, 2013), where Jurassic, Cretaceous, Paleogene, Neogene and Quaternary rocks represent 70\% of the reservoirs, with few occurrences of older ages. Some well-known examples of Mesozoic basins with igneous reservoirs that have already been explored or are still being explored are: the Campos Basin, in Brazil (Tigre et al., 1983; Bruhn et al., 2003; Rodriguez et al., 2018); the Neuquén and Austral, in Argentina (Venara et al., 2009; Spacapan et al., 2018). For Cenozoic basins, some examples of volcanic reservoirs are the Cambay, in India (Farooqui et al., 2009); the Niigata and Akita, both in Japan (Racey, 2018); the Petchabun, Thailand and the Kura in Azerbaijan and Georgia; as well as the Utah and Nevada basins in the United States (Schutter, 2003).

From the compilation of previous studies, it was possible to update these age data and add new examples from the Proterozoic and Archean (supplementary material). In the diagram shown in figure 6 , it is possible to observe that $48.1 \%$ of volcanic reservoirs are Cenozoic, followed by $32.9 \%$ of Mesozoic ages, $16.5 \%$ of Paleozoic ages. This result corroborates and updates data of authors such as Schutter (2003) and Petford \& McCaffrey (2003). To a lesser extent, $2.5 \%$ is equivalent to Proterozoic and Archean, in which the reservoirs are often associated with fractured basements (Koning, 2014).
In the case of older ages, in particular, the presence of fault and fracture zones is important for the exploration of fractured basement reservoirs (Trice et al., 2019). These fractures develop an interconnected system that contributes to increasing the permeability of reservoir and also allowing the hydrocarbon migration, as shown in figure 7. Currently, four fields stand out in the fractured economic basement: Zeit Bay (Egypt); Bach Ho (Vietnam); La Paz (Venezuela); and Dongshengpu (China) (Koning, 2014).

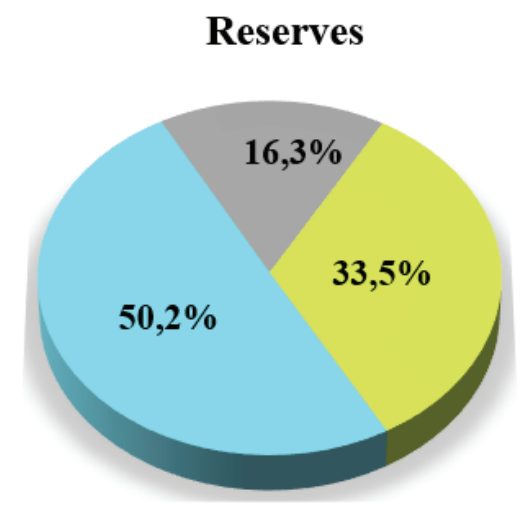

\section{Commercial Non commercial $\square$ No information}

Figure 5. Commerciality of oil and gas reserves in igneous reservoirs.

Figura 5. Comercialidade das reservas de óleo e gás em rochas ígneas. 
Chart 1. Largest global oil and gas reserves in igneous reservoirs by country, in decreasing order of reserves. Source: Xiaohong (2016).

Quadro 1. Grandes reservas de óleo e gás em reservatórios ígneos por país, em ordem decrescente de reservas. Fonte: Xiaohong (2016).

\begin{tabular}{|c|c|c|c|c|c|c|}
\hline \multirow{2}{*}{ Country } & \multirow{2}{*}{ Fields } & \multirow{2}{*}{ Basins } & \multirow{2}{*}{ Fluid } & \multicolumn{2}{|c|}{ Reserves } & \multirow{2}{*}{ Lithologies } \\
\hline & & & & Gas $\left(10^{8} \mathrm{~m}^{3}\right)$ & Oil (10 $10^{4}$ ton) & \\
\hline China & & More than 11 & & 4,7 & 60 & \\
\hline Cuba & Cristales & Cuba North & Oil & 3,425 & & Basaltic tuffs \\
\hline Vietnam & $12-2-R D 1 X$ & Cuu Long & Oil & 1,37 & & Altered granite \\
\hline Argentina & $\begin{array}{l}\text { YPF Palmar } \\
\text { Largo }\end{array}$ & North-western & Oil and gas & 550 & 3.4 & Porous basalts \\
\hline Georgia & Samgori & & Oil & 411 & & Tuffs \\
\hline Venezuela & Totumo & Maracaibo & Oil & 288 & & Volcanics \\
\hline Argentina & Veja Grande & Neuquén & Oil and gas & 244 & & $\begin{array}{l}\text { Fractured } \\
\text { andesites }\end{array}$ \\
\hline New Zealand & Kora & Taranaki & Oil & 160 & & Andesitic tuffs \\
\hline Japan & $\begin{array}{c}\text { Yoshii- } \\
\text { Kashiwazaki }\end{array}$ & Niigata & Gas & 118 & 49.5 & Rhyolites \\
\hline Australia & Scotia & Bowen-Surat & Gas & & 17.8 & $\begin{array}{l}\text { Fractured } \\
\text { andesites }\end{array}$ \\
\hline
\end{tabular}

Another important aspect is the geological location of igneous reservoirs. Almost all occurrences of oil and gas in igneous rocks are found onshore. In some countries like Brazil, occurrences have already been identified offshore (Fig. 4), such as the Badejo and Linguado fields, in the economic basement of the Campos Basin (Mizusaki et al., 1992 and 2008; Reis, 2013; Dani et al., 2017). According to Tigre et al. (1983), the initial production rate in the Badejo field reached 6,200 BOPD. However, productivity declined, even though it stabilized, for some decades, in a production of approximately 2,000 BOPD (Guardado et al., 1990; Bruhn et al., 2003). The Brazilian fields case has two highlights: the first is that igneous rocks and their thermal influence have a secondary importance, as it happens in other countries, even though they are quite common in sedimentary basins (Thomaz Filho et al., 2008; Costa et al., 2016; Miranda et al., 2018; Penna et al., 2018; Cioccari \& Mizusaki, 2019; Fornero et al., 2019; Correia et al., 2019; Avellar \& Pereira, 2019); and second is about the complexity in offshore regions added to the presence of the pre-salt, especially in prospects of microbial carbonates and coquinas, as noted by De Luca et al. (2015). In other words, better understanding the igneous rock can improve the characterization of reservoirs (sometimes in a complex geology site) as a whole, in the oil system in general, since its presence is recurrent in many prospects.

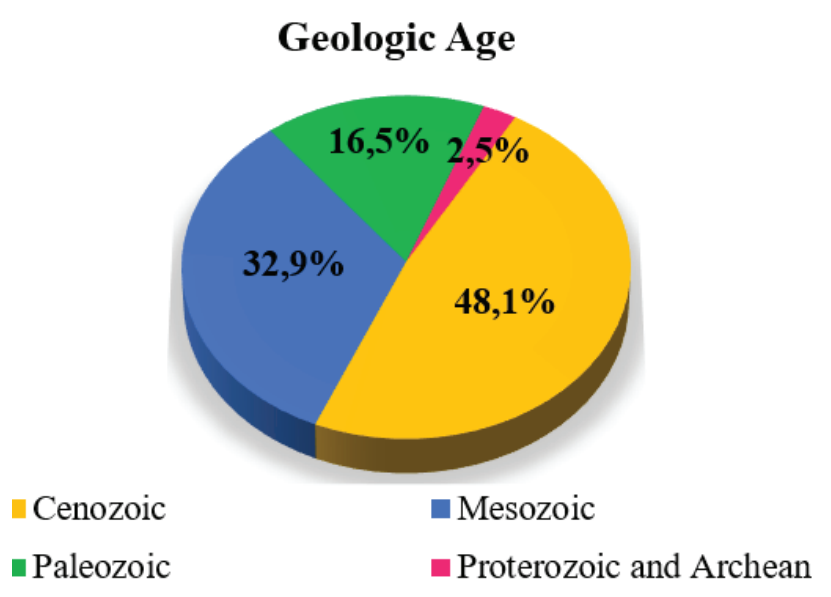

Figure 6. Distribution of global igneous reservoirs by geological age.

Figura 6. Distribuição dos reservatórios ígneos globais por idade geológica. 


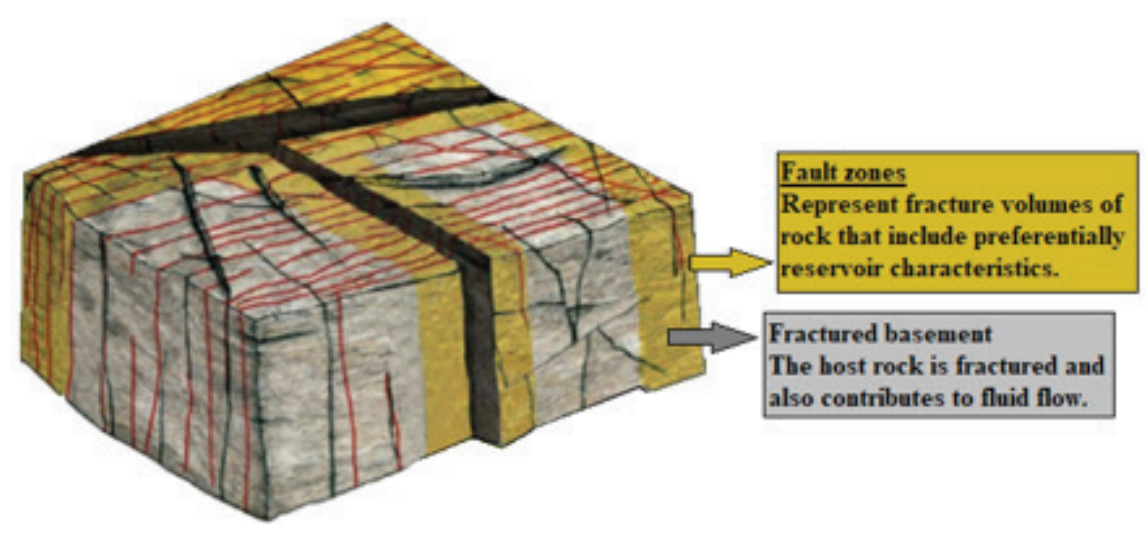

Figure 7. Fractured basement model. Adapted from Trice et al. (2019).

Figura 7. Modelo de embasamento fraturado. Adaptado de Trice et al. (2019).

Some lithologies are more frequent in volcanic reservoirs. Couves (2015) proposed a diagram where the following lithologies associated with hydrocarbon storage were present (in descending order of occurrence): basalts, andesites, rhyolites, volcaniclastics, syenites/trachytes, granites, kimberlites, and peridotites. Where the first four lithologies are recurrent in commercial productions. Figure 8 shows the update of these data, adding the new reserves, according to supplementary material.

The same pattern of lithologies, considered as most common for hydrocarbon storage and, therefore, attractive to the oil industry, is still the same as previous estimations (Schutter, 2003; Couves, 2015): basalts (38.5\%), andesites (15.9\%), volcaniclastics (12.1\%) and rhyolites (11.5\%). We highlight here the presence of the diabase, currently make up $11.0 \%$ of these reservoirs. In previously studies, the diabase was included in the group of the minor contributions.

\section{Lithology}

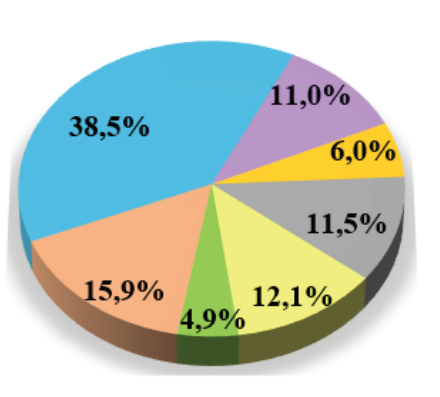

Figure 8. Igneous rocks associated with hydrocarbon storage.

Figura 8. Rochas ígneas associadas com armazenamento de hidrocarbonetos.

\subsection{Geophysical aspects}

The acquisition, processing, and interpretation of geophysical data, in association with regional geology, on a larger scale, play a fundamental role in the mapping and identification of igneous bodies and, mainly, in the influence of magmatism in the petroleum system, which has been gaining greater attention both from research institutions and from the oil and gas industry.

The most applicable geophysical methods for the study of igneous rocks is the standard workflow seismic-logs-rocks, but other methods such as gravimetry and magnetometry are used in joint interpretations to better delimit these bodies. The expected physical responses of igneous rocks are commonly observed at high values of gravity and magnetic susceptibility (Trice et al., 2019; Planke et al. 2015; Liu et al., 2019).

Works such as Tan et al. (2016) and Trice et al. (2019), approach the importance of the seismic processing step, using filters to increase the signal/noise ratio, removing multiples, the greater amplitude at the igneous top and better resolution in failures and fractures. Additionally, it is important the application of migration algorithms to improve the imaging of these bodies and the extracting seismic attributes to better characterize these igneous rocks, especially the extrusive ones, such as curvature, apparent dip, and energy gradient are applied to better visualize regions with potential reservoirs. The typical energy loss and the chaotic seismic pattern, in the case of extrusives and the most 
luminous reflections of amplitude, in the case of intrusive and extrusive (Planke et al., 2015).

Physical properties such as velocity and density in igneous rocks are highly dependent on the type of volcanic facies (Planke et al., 1994; Nelson et al., 2009; Rossetti et al., 2019) and, mainly, of considerable dimensions so that it is possible to detect them in seismic and well data. The last authors also highlight the variation in the velocity of seismic waves, in the same igneous unit, due to geochemical factors and the presence of fluids, which can vary from 5.80 to $4.30 \mathrm{~km} / \mathrm{s}$ and density from 2.69 to $2.89 \mathrm{~g} / \mathrm{cm}^{3}$, obtained by petrophysics in samples from igneous provinces of the North Atlantic.

Igneous bodies, in general, have seismofacies that vary from transparent to strong contrasts of acoustic impedance. Low amplitude and reflection disturbances are observed in hydrothermal vents complexes (Angkasa et al., 2017). Lava flows in contact to siliciclastic sediments often have strong contrast of positive acoustic impedance. This pattern occurs at the top of an igneous sequence, where amygdaloidal basalts are present. At the top, a low gamma-ray response combined with high-resistivity, highdensity, and an interval compressional velocity of approximately $4.5 \mathrm{~km} / \mathrm{s}$ are observed. While at the base, where there are volcanoclastic breccias, low values of resistivity and density are observed, and seismic velocity of $3.4 \mathrm{~km} / \mathrm{s}$ (Cortez \& Cetale, 2016).

Mark et al. (2018) point out that the integration of various physical responses of logs further contributes to the identification of acidic and basic intrusions, since the acidic rocks are less detectable in seismic lines due to their poor response in compressional velocity. In general, the authors highlight that the high amplitude nature of the mafic intrusions results from their high acoustic impedance relative to the surrounding host rock sediments, which is a product of their high density $\left(2.8-3.0 \mathrm{~g} / \mathrm{cm}^{3}\right)$ and compressional velocities $(5.5-6.6 \mathrm{~km} / \mathrm{s})$, which converts to 45 $55 \mu \mathrm{s} / \mathrm{ft}$ and shear velocities within the range 2.4$3.4 \mathrm{~km} / \mathrm{s}$

The density of igneous rocks has systematic variations for acidic (silica content greater than 66\%), intermediate (silica content between 66 and
$52 \%$ ), and basic rocks (silica content less than $52 \%)$. The typical high-densities in basic rocks (such as basalt) are due to the mafic minerals and high-temperature feldspars (Farooqui et al., 2009). The authors point out that basic rocks have a range of densities between 3.2 and $4.2 \mathrm{~g} /$ $\mathrm{cm}^{3}$. As silica content increases, in acidic rocks, density value decreases and varies between 2.55 to $2.62 \mathrm{~g} / \mathrm{cm}^{3}$. High-density peaks, between 4.80 and $5.17 \mathrm{~g} / \mathrm{cm}^{3}$, are observed when pyrites is present, even when dispersed in igneous rocks.

Drilling in igneous rocks can be costly, as highlighted by Lyons \& Plisga (2011), due to rock high-density. However, the authors claim that this fact is true for basaltic rocks, while acidic volcanic rocks, such as dacites or other with associated tufts, have a cost comparable to drilling in sandstones, shales and siltstones, either onshore or offshore. Millett et al. (2016) address several points in which basaltic rocks can represent a problem for profiling, such as variations in the rate of penetration (ROP), loss of fluids, high-pressure formations can lead to the collapse of wells, being more difficult on top of thick volcanic packages, due to secondary hydrothermal alteration. The authors point out that such problems can be overcome when one has a good knowledge of drilling monitoring (mudlogging) and well logging (WL or LWD).

Thecombination of densityand photoelectric factor logs, provides the igneability feature, which indicates the presence of igneous rocks, as described by Oliveira et al. (2019). It is applied in combination with dry weight lithogeochemical logs, with Fe-Al-Ca feature to distinguish mafic rock from limestone and clay zones, while Si-Al feature indicates aluminosilicate sites.

Gamma-ray logs are related to the abundance of radioactive elements, such as uranium, potassium, and thorium, which in the case of igneous is related to the primary composition of the magma, for example, basalts have a low content of these elements (Jerram et al., 2019). So, the gamma-ray log would be better used to define lithological contacts and chemical composition through the potassium content that has its value increased from basic to acidic rocks. Similar behaviour is observed in thorium and uranium readings, but they are fewer sensitive 
elements to differentiate igneous lithologies. Values between 9 to $30 \mathrm{API}$ responses are commom in mafic intrusions (Mark et al., 2018).

Delpino \& Bermúdez (2009) point out that acid rocks have a greater response in relation to radioactive elements and, therefore, a more sensitive gamma-ray reading and a more convex curve. This behaviour is the opposite of basic rocks, where low values of gamma-ray and more concave are expected, where peaks would be likely to represent fractures zones. Anomalies in this sense can be secondary changes where, in most cases, the presence of chlorites implies the loss of potassium and the presence of zeolites and clays implies an increase in potassium. The combined use of gamma-ray and density logs can minimize this ambiguity, as an example, for acidic rocks (higher silica content), the density logs show a decrease of this property in comparison to basic rocks.

Resistivity curves are influenced by lithology, porosity, permeability, saturation, metal content, and compaction (Liu et al.,2013). If no fractures occur, the resistivity values tend to increase. In intensely fractured rock, the resistivity can be high or low depending on the type of fluid present in the pores. Polteau et al. (2008) and Chowdhury et al. (2014) showed that sills and laccoliths tend to have high-resistivity, but the presence of sulphides (such as pyrite) in the form of veins or disseminated within intrusions can cause variations in the log response. The presence of sulphides is caused by the dissolution and mixture of silicates and magmatic gases $\left(\mathrm{SO}_{2}, \mathrm{CO}_{2}\right.$, and $\mathrm{SH}_{2}$ ), which causes a decrease in pressure and, consequently, precipitation of the material. Rocks that have a higher content of organic matter may contain graphite minerals, which would make the medium more conductive, thus generating a reduction in resistivity. The same behaviour is expected when carbonate is precipitated by hydrothermal fluids, either in hydrothermal vents or cavities. In the case of layers of lavas and basaltic lobes, vesicles and fractures (common at the top of these sequences) cause decreases in the density, resistivity and velocity curves (Nelson et al., 2009). Fewer vesicles are often found at the flow core and base, consequently, a lower response is expected.
Ren et al. (2019) present the behaviour of logs in basic intrusions where high density and resistivity, low acoustic response, and peaks of the $T_{2}$ distribution (NMR logs) are expected below the cut off line, which suggests, as expected, low porosity. The response of mafic intrusions in neutron logs is addressed by Mark et al. (2018), which identifies variations from 0.08 to 0.10 units of porosity. In general, this log measures the hydrogen content within the formation porous. These values are generally low for crystalline igneous rocks.

The use of crossplots from well-logs also contributes to subdivide the igneous facies. Souza-Lima (2006) points out two diagrams: one of neutron-density versus porosity and another diagram using sonic, gamma-ray, and deep resistivity.

Analysing in the smaller-scale view, image logs have also been applied for the interpretation of smaller scale volcanic facies (0.13 to 0.50 inches), as exposed by Fornero et al. (2019). The study shows both microresistivy (OBMI) and microacoustic (UBI) logs, allow the visualization of vesicles, amygdalas, joints, fractures and massive regions (Figure 1).

The degree of alteration of volcanic rock is the key to the development of porosity and, therefore, petrophysical studies are fundamental for the characterization of volcanic reservoirs (Chowdhury et al., 2014; Rossetti et al., 2019). Couves (2015) presents some preliminary world data on the main petrophysical properties of volcanic rocks. Average porosity values (including primary and secondary) and permeability are summarized in chart 2. Such averages show how these properties can be quite heterogeneous in igneous rocks when compared with conventional reservoir rocks.

The author also pointed out that the global average values of porosity and permeability can vary depending on the lithology. For example, in volcaniclastic (25\% and $107 \mathrm{mD}$ ), basaltic flows (22\% and $80 \mathrm{mD}$ ), andesites (26\% and $80 \mathrm{mD}$ ), and rhyolites ( $27 \%$ and $65 \mathrm{mD}$ ). Significant volumes of condensed gas and oil that are produced in this variety of lithologies with a range of porosity and permeability values ranging from 0.1 to $56.7 \%$ and 0.001 to $762 \mathrm{mD}$, respectively (Liu et 
Chart 2. Average porosity and permeability values in igneous rocks demonstrating the wide petrophysical variability. Source: Couves (2015).

Quadro 2. Valores de porosidade e permeabilidade média em rochas ígneas demonstrando a ampla variabilidade petrofísica. Fonte: Couves (2015).

\begin{tabular}{|c|c|c|c|}
\hline Country & Porosity (\%) & Permeability (mD) & Lithologies \\
\hline Japan & $7.0-32.0$ & 150.0 & $\begin{array}{c}\text { andesites, rhyolites, basalts, } \\
\text { dacites, dolerites and tuffs }\end{array}$ \\
\hline United States & $2.0-70.0$ & $0.1-10.0$ & $\begin{array}{c}\text { tuffs, ignimbrites, basalts and } \\
\text { serpentinites }\end{array}$ \\
\hline New Zealand & $9.5-26.0$ & $0.2-64.0$ & andesites and basalts \\
\hline Mexico & $1.4-56.7$ & $0.2-211.0$ & andesites and ignimbrites \\
\hline Georgia & $1.5-20.7$ & $0.002-159.0$ & $\begin{array}{c}\text { tuffs and andesites } \\
\text { basalts e rhyolites }\end{array}$ \\
\hline India & $10.0-40.0$ & 0.4 & $\begin{array}{c}\text { tuffs, rhyolites, ignimbrites, } \\
\text { andesites }\end{array}$ \\
\hline Argentina & $2.0-37.6$ & $0.002-762.0$ & $\begin{array}{c}\text { basalts, rhyolites and } \\
\text { pyroclastics }\end{array}$ \\
\hline Chile & $0.2-23.0$ & $0.1-60.0$ & $\begin{array}{c}\text { basalts, tutfs, diabases, } \\
\text { andesites, rhyolites and } \\
\text { dacites }\end{array}$ \\
\hline China & $0.1-70.0$ & $0.0007-313.9$ & \begin{tabular}{c} 
\\
\hline
\end{tabular}
\end{tabular}

al., 2013). In some cases, this permeabilities can reach 10 D (Saar \& Manga, 1999).

Primary porosities occur in vesicles, fractures, and intergranular pore spaces, while secondary porosity develops due to hydrothermal alterations, weathering, and tectonism. Cooling joints in igneous rocks can connect pores and evolve to areas of weakness, which generate fractures, as well as the occurrence of micropores in mineral dissolution sites (Farooqui et al., 2009).

\section{Discussions and conclusions}

Many countries already have solid technology, inherited from half a century of development in applied research, to improve the detection and characterization of their igneous reservoirs. The complexity of research being developed involves advanced methodologies, such as interpretations of 3D seismic data, the use of potential methods, conventional and special log-curves. There is also research being developed which aims the production phase of these reservoirs, such as hydraulic fracturing, for the stimulation of the reservoir, and phases of reprocessing of advanced geophysical data. The evolution in the last decades is remarkable, with pioneering creations of solid analysis and methodologies to identify volcanic reservoirs with greater efficiency.

Dealing with igneous rocks in petroleum systems requires an initial appropriate workflow. A basic methodology was suggested by Ran et al (2014), which consists in characterizing the type of basin (rift, marine, transitional or lake), the geological age of the reservoir and, finally, the type of igneous rock (the type defines if it is more likely to accommodate hydrocarbons). Regarding the understanding of volcanic architecture, Zou (2013) addresses the importance of developing a better understanding of eruption modes, patterns of distribution of volcanic bodies, lithologies and facies characterization, formation mechanisms, petrophysical data and characteristics of fluids.

Exploratory success, is therefore, strongly related to the geological conditions of the environment in which the rock was cooled. The permo-porous properties of these igneous rocks 
have been underestimated in exploration for decades, as explained by Zahedi \& MacDonald (2018). Understanding the petroleum system requires, a better comprehension of these rocks since they are often found nearby and even as prospects in volcanic basins. How, for example, would an igneous rock be one of the reservoirs in the pre- and post-salt? As observed in the Santos and Campos Brazilian basins in fractured Cretaceous basalts of the syn-rift phase by De Luca et al. (2015), as well as Fornero et al. (2019) lavas flow units. Would a volcanic rock get a prominent role in geological and/or geophysical studies of a basin? The advancing of several studies led to new discoveries, suggesting these responses as positive.

Finally, whether in extrusive or intrusive rocks, some authors such as Farooqui et al. (2009), Petford \& McCaffrey (2003), Miranda (2014), Jerram (2015), Senger et al. (2017), Planke et al. (2018), claim that great discoveries can be achieved when special attention is paid to this type of rock within the hydrocarbon industry. We emphasize that a study integrating geology, geophysics and engineering can improve the understanding of volcanic rocks, which may result in timely discoveries of oil fields.

Acknowledgements. The authors would like to thank the CNPq and Capes for their doctoral and master's scholarships, from the first and third authors.

\section{References}

Angkasa, S., Jerram, D.A., Millett, J.M., Svensen, H.H., Planke, S., Taylor, R.A., Schofield, N. \& Howell, J. 2017. Mafic intrusions, hydrothermal venting, and the basaltsediment transition: Linking onshore and offshore examples from the North Atlantic igneous province. Interpretation, 5(3): SK83SK101.

Avellar, G. \& Pereira, E. 2019. Unravelling magmatic activity in sedimentary basins: sills and related brittle structures affecting Campos Basin petroleum system (SE Brazil). Journal of Sedimentary Environments, 4(4): 471-479.

Bawazer, W., Lashin, A. \& Kinawy, M. 2018.
Characterization of a fractured basement reservoir using high-resolution 3D seismic and logging datasets: A case study of the Sab'atayn Basin, Yemen. Plos One, 13(10): e0206079.

Bishop, M.G. 2009. Petroleum Systems of the Northwest Java Province, Java and Offshore Southwest Sumatra, Indonesia, "USGS OpenFile Report 99-50R. Available from: <http:// pubs.usgs.gov/of/1999/ofr-99-0050/OF9950R/ardj_occr.html>. Cited in 2019 July 03.

Bischoff, A.P. 2019. Architectural elements of buried volcanic systems and their impact on geoenergy resources. New Zealand, 226p. Ph.D. Thesis, Department of Geological Sciences, Canterbury University.

Bruhn, C.H., Gomes, J.A.T., Del Lucchese Jr, C. \& Johann, P.R. 2003. Campos Basin: reservoir characterization and management - Historical overview and future challenges. In: OFFSHORE TECHNOLOGY CONFERENCE, 2003, Houston. Anais...OTC, p. 14.

Cioccari, G.M. \& Mizusaki, A.M.P. 2019. Atypical petroleum systems in Brazilian paleozoic basins - A Review. Geociências, 38(2): 367390.

Chowdhury, M., Guha, R., Singh, S., Verma, S.K., Tandon, R., Gould, T. \& Taylor, A. 2014. Characterization of volcanic reservoir-New integrated approach: A case study from Raageshwari Deep Gas Field, Rajasthan, India. In: INTERNATIONAL PETROLEUM TECHNOLOGY CONFERENCE, 2014, Kuala Lampur. Anais...Kuala Lampur, IPTC.

Conceição, J.C.J., Zalán, P.V. \& Dayan, H. 1993. Deformations in sedimentary rocks induced by magmatic intrusions: classification and intrusion mechanisms. Boletim de Geociências da Petrobras, 7(1/4): 57-91.

Correia, U.M., Honório, B.C.Z., Kuroda, M. C., Melani, L.H. \& Vidal, A.C. 2019. Geometric characterization of igneous intrusions: 3D seismic insights from the Campos Basin, SE Brazil. Marine and Petroleum Geology, 102: 725-739.

Couves, C.R. 2015. Investigating the petrophysical properties of volcanic reservoir analogues through the use ofmicro-focus $x$-ray computed tomography. Southampton, 317p. Ph.D. 
thesis, Faculty of Natural and Environmental Sciences, University of Southampton.

Cuong T.X. \& Warren, J.K. 2009. Bach Ho Field, a fractured granitic basement reservoir, Cuu Long Basin, offshore SE Vietnam: A "buried hill" play. Journal of Petroleum Geology, 32(2): 129-156.

Dani, A.P., Remus, M.V.D., Dani, N. \& de Lima, E.F. 2017. Basaltic magmatism of the Alagoas Floor (Campos Basin). Geologia USP, Série científica, 17(2): 269-287.

De Luca, P., Carballo, J., Filgueiras, A., Pimentel, G., Esteban, M., Tritlla, J. \& Villacorta, R. 2015. What is the Role of Volcanic Rocks in the Brazilian Pre-salt? In: $77^{\text {th }}$ EAGE CONFERENCE AND EXHIBITION, 2015, Madri. Anais...Madri, EAGE, v. 2015, n. 1, p. 1-5.

Delpino, D.H. \& Bermúdez, A.M. 2009. Petroleum systems including unconventional reservoirs in intrusive igneous rocks (sills and laccoliths). The Leading Edge, 28(7): 804-811.

Duarte, O.D.O. 1997. English-Portuguese encyclopedic dictionary of geophysics and geology. São Paulo, SBGF, 304p.

Eiras, J.F. \& Wanderley Filho, J.R. 2003. Igneous oil systems. In: ABPG, CONGRESSO BRASILEIRO DE PESQUISA E DESENVOLVIMENTO EM PETRÓlEO E GÁS, 2, 2003, Rio de Janeiro. Boletim de Resumos....Rio de Janeiro, SBG, v. 1 .

Farooqui, M.Y., Hou, H., Li, G., Machin, N., Neville, T., Pal, A., Shrivastva, C., Wang, Y., Yang, F., Yin, C., Zhao, J. \& Yang, X. 2009. Evaluating volcanic reservoirs. Oilfield Review, 21(1): 3647.

Fornero, S.A., Marins, G.M., Lobo, J.T., Freire, A.F.M. \& de Lima, E.F. 2019. Characterization of subaerial volcanic facies using acoustic image logs: Lithofacies and log-facies of a lava-flow deposit in the Brazilian Pre-salt, deepwater of Santos Basin. Marine and Petroleum Geology, 99: 156-174.

Fridleifsson, G.O. \& Elders, W.A., 2005. The Iceland Deep Drilling Project: a search for deep unconventional geothermal resources. Geothermics, 34: 269-285.

Greenfield, L., Millett, J. M., Howell, J., Jerram, D. A., Watton, T., Healy, D., Hole, M. \& Planke, S. 2019. The 3D facies architecture and petrophysical properties of hyaloclastite delta deposits: An integrated photogrammetry and petrophysical study from southern Iceland. Basin Research, 32(5): 1081-1104.

Guardado, L.R., Gamboa, L.A.P. \& Lucchesi, C.T. 1990. Petroleum geology of the Campos Basin, Brazil, a model for a producing Atlantic type basin. AAPG Memoir, 48: 3-79.

Holford, S.P., Schofield, N. \& Reynolds, P. 2017. Subsurface fluid flow focused by buried volcanoes in sedimentary basins: Evidence from 3D seismic data, Bass Basin, offshore southeastern Australia. Interpretation, 5(3): SK39-SK50.

Hu, Z., Zhang, S., Wu, F., Liu, X., Wu, J., Li, S., Wang, y., Zhao, X. \& Zhao, H. 2019. Effective Igneous Reservoir Identification and Controlling Factor Analysis in Eastern Sag of Liaohe Depression, China. In: INTERNATIONAL PETROLEUM TECHNOLOGY CONFERENCE, 2019, Beijing. Anais...Beijing, IPTC, v. 1, p. 18.

Infante-Paez, L. \& Marfurt, K.J. 2018. Incontext interpretation: Avoiding pitfalls in misidentification of igneous bodies in seismic data. Interpretation, 6(4): SL29-SL42.

Jerram, D.A., Single, R.T., Hobbs, R.W. \& Nelson, C.E. 2009. Understanding the offshore flood basalt sequence using onshore volcanic facies analogues: an example from the Faroe Shetland basin. Geological Magazine., 146(3): 353-367.

Jerram, D.A. 2015. Hot rocks and oil: Are volcanic margins the new frontier. Exploration \& Production. Elsevier R\&D Solutions.

Jerram, D.A., Millett, J.M., Kück, J., Thomas, D., Planke, S., Haskins, E., Lutze, N. \& Pierdominici, S. 2019. Understanding volcanic facies in the subsurface: a combined core, wireline logging and image log data set from the PTA2 and KMA1 boreholes, Big Island, Hawaii. Scientific Drilling, 25: 15-33.

Jiang, H., Guo, J. \& Guo, S. 2010. Current situation and prospect on E\&P of global igneous rock gas reservoirs. Natural Gas Technology, 4(2): 8-10.

Kennedy, B., Heap, M., Bischoff, A., Nicol, A., Villeneuve, M., Farquharson, J. \& Cole, J. 2017. Insights into volcanic rocks as petroleum reservoirs from laboratory and field 
permeability measurements. In: CONFERENCE ON OF VOLCANISM AND ASSOCIATED MAGMATIC PROCESSES ON PETROLEUM SYSTEMS, 2017, Oamuru. Anais...Oamuru, AAPG.

Koning, T. 2014. Global accumulations of oil and gas in fractured and weathered basement: Best practices for exploration and production. AAPG Search and Discovery Article, 20281(4).

Kumar, P.C., Sain, K. \& Mandal, A. 2019. Delineation of a buried volcanic system in Kora prospect off New Zealand using artificial neural networks and its implications. Journal of Applied Geophysics, 161: 56-75.

Landes, K.K., Amoruso, J.J., Charlesworth Jr, L.J., Heany, F. \& Lesperance, P.J. 1960. Petroleum resources in basement rocks. AAPG Bulletin, 44(10): 1682-1691.

Lenhardt, N. \& Götz, A. E. 2011. Volcanic settings and their reservoir potential: An outcrop analog study on the Miocene Tepoztlán Formation, Central Mexico. Journal of Volcanology and Geothermal Research, 204(1/4): 66-75.

Liu, J., Wang, P., Zhang, Y., Bian, W., Huang, Y., Tang, H. \& Chen, X. 2013. Volcanic rock-hosted natural hydrocarbon resources - A Review. In: Nemeth, K. (Ed.). Updates in Volcanology - New Advances in Understanding Volcanic Systems. London, IntechOpen, p. 151-179.

Liu, G., Scott, R. \& O'Halloran, G. 2019. Gravity and magnetic data applications for hydrocarbon exploration offshore NW Australia. In: SEG TECHNICAL PROGRAM EXPANDED ABSTRACTS, 2019, San Antonio. Anais...San Antonio, SEG, p. 1695-1698.

Millett, J.M., Wilkins, A.D., Campbell, E., Hole, M.J., Taylor, R.A., Healy, D., Jerram, D.A., Jolley, D.W., Planke, S., Archer, S.G. \& Blischke, A. 2016. The geology of offshore drilling through basalt sequences: Understanding operational complications to improve efficiency. Marine and Petroleum Geology, 77: 1177-1192.

Miranda, F.S. 2014. Pimenteiras Shale: Characterization of an atypical unconventional petroleum system, Parnaiba Basin, Brazil. In: AAPG INTERNATIONAL CONFERENCE \& EXHIBITION, 2014, Houston. Anais... Houston, AAPG.

Miranda, F.S., Vettorazzi, A.L., da Cruz Cunha,
P.R., Aragão, F.B., Michelon, D., Caldeira, J.L., Porsche, E., Martins, C., Ribeiro, R.B., Vilela, A.F., Corrêa, J.R., Silveira, L.S. \& Andreola, K. 2018. Atypical igneous-sedimentary petroleum systems of the Parnaiba Basin, Brazil: seismic, well logs and cores. Geological Society London Special Publications, 472(1): 341-360.

Mizusaki, A.M.P., Petrini, R., Bellieni, P., CominChiaramonti, P., Dias, J., De Min, A. \& Piccirillo, E. M. 1992. Basalt magmatism along the passive continental margin of SE Brazil (Campos Basin). Contributions to Mineralogy and Petrology, 111(2): 143-160.

Mund, B., Das, A., Sharda, R., Bhat, S., Kumar, R., Gupta, A.K. \& Shankar, P. 2017. Unravelling Potential of a Volcanic Reservoir Through Enhanced Facies Understanding-A Case Study from Barmer Basin, India. In: SPE OIL AND GAS INDIA CONFERENCE AND EXHIBITION, 2017, Mumbai. Anais...Mumbai, SPE.

Nelson, C.E., Jerram, D.A. \& Hobbs, R.W. 2009. Flood basalt facies from borehole data: implications for prospectivity and volcanology in volcanic rifted margins. Petroleum Geosciences, 15: 313-324.

Oliveira, F.V, Gomes, R.T.M. \& Silva, K.M.S. 2019. Log features for the characterization of igneous rocks in the Pre-Salt area of Santos Basin, SE Brazil. In: AAPG ICE 2019, Buenos Aires. Anais...Buenos Aires, p. 835.

Patil, R.M., Koduru, A.K., Murthy, P.V.R., Pande, K. \& Bhatia, K. 2018. Unlocking the potential of naturally fractured basal clastic volcanic rock using hydraulic fracturing: First successful campaign conducted in Mumbai High Field, India. In: OFFSHORE TECHNOLOGY CONFERENCE ASIA, 2018, Kuala Lampur. Anais...Kuala Lampur, OTC, p. 504.

Penna, R., Araújo, S., Geisslinger, A., Sansonowski, R., Oliveira, L., Rosseto, J. \& Matos, M. 2018. Igneous rock characterization through reprocessing, FWI imaging, and elastic inversion of a legacy seismic dataset in Brazilian Pre-SaltProvince. In:SEG TECHNICAL PROGRAM EXPANDED ABSTRACTS, 2018, Anaheim. Anais...Anaheim, SEG, p. 3277-3281. Petford, N. \& McCaffrey, K. 2003. Hydrocarbons in crystalline rocks: An introduction. London, Geological Society London Special 
Publications, 214: 1-5.

Planke, S., 1994. Geophysical response of flood basalts from analysis of wire line logs: Ocean Drilling Program Site 642, Voring volcanic margin. Journal of Geophysical Research, 99: 9279-9296.

Planke, S., Svensen, H., Myklebust, R., Bannister, S., Manton, B. \& Lorenz, L. 2015. Geophysics and remote sensing. In: Breitkreuz, C. \& Rocchi, S. (Eds.). Physical geology of shallow magmatic systems. London, Springer, p. 131-146.

Planke, S., Rabbel, O., Galland, O., Millett, J.M., Manton, B., Jerram, D.A., Palmas, O. \& Spacapan, J.B. 2018. Seismic imaging and petroleum implications of igneous intrusions in sedimentary basins constrained by outcrop analogues and seismic data from the Neuquén basin and the NE Atlantic. In: $10^{\circ}$ CONGRESO DE EXPLORACIÓN Y DESARROLLO DE HIDROCARBUROS, 2018, Mendoza. Anais... Mendoza, IAPG.

Polteau, S. Mazzini, A., Galland, O., Planke, S. \& Malthe-Sørenssen, A. 2008. Saucer-shaped intrusions: Occurrences, emplacement and implications. Earth and Planetary Science Letters, 266(1/2): 195-204.

Powers, S. 1932. Notes on minor occurrences of oil, gas, and bitumen with igneous and metamorphic rocks. AAPG Bulletin, 16(8): 837-858.

Quirie, A.K., Schofield, N., Hartley, A., Hole, M.J., Archer, S.G., Underhill, J.R., Watson, D. \& Holford, S.P. 2018. The Rattray Volcanics: Mid-Jurassic fissure volcanism in the UK Central North Sea. Journal of the Geological Society, 176(3): 462-481.

Rabbel, O., Galland, O., Mair, K., Lecomte, I., Senger, K., Spacapan, J.B. \& Manceda, R. 2018. From field analogues to realistic seismic modelling: a case study of an oil-producing andesitic sill complex in the Neuquén Basin, Argentina. Journal of the Geological Society, 175(4): 580593.

Racey, A. 2018. Volcanic Reservoirs of SE Asia. In: PESGB/SEAPEX ASIA PACIFIC E\&P CONFERENCE OLYMPIA EXHIBITION CENTRE, 2018, London. Anais...London, PESGB/ SEAPEX.

Ran, Q., Wang, Y., Sun, Y., Yan, L. \& Tong, M.
2014. Volcanic gas reservoir characterization. Amsterdam, Elsevier, 604p.

Ran, Q., Ren, D. \& Wang, Y. 2018. Development of volcanic gas reservoirs: The theory, key technologies and practice of hydrocarbon development. Beijing, Gulf Professional Publishing, 1078p.

Rauzi, S.L. 2001. Arizona has Oil \& Gas Potential! Arizona Geological Survey Circular, 29: 1-40.

Reis, G.D.S. 2013. A Formação Serra Geral (Cretáceo, Bacia do Paraná) como análogo para reservatórios ígneos-básicos damargem continental brasileira. Porto Alegre, 73p. Dissertação de mestrado, Programa de Pósgraduação em Geociências, Instituto de Geociências, Universidade Federal do Rio Grande do Sul

Rodriguez, K., Hodgson, N. \& Intawong, A. 2018. Fractured basement initial identification methodology. In: 80 th EAGE CONFERENCE AND EXHIBITION, 2018, Copenhagen. Anais... Copenhagen, EAGE, p. 1-5.

Rossetti, L.M., Healy, D., Hole, M.J., Millett, J.M., de Lima, E.F., Jerram, D.A. \& Rossetti, M.M. 2019. Evaluating petrophysical properties of volcano-sedimentary sequences: A case study in the Paraná-Etendeka Large Igneous Province. Marine and Petroleum Geology, 102: 638-656.

Saar, M.O. \& Manga, M. 1999. Permeabilityporosity relationship in vesicular basalts. Geophysical Research Letters, 26: 111-114.

Sarkar, S. \& Marfurt, K.J. 2017. Effect of volcanic bodies on hydrocarbon reservoirs in the northeastern part of the Chicontepec Foredeep, Mexico. Interpretation, 5(3): SK1-SK10.

Schmoker, J.W., Dyman, T.S., Dolton, G.L., Fox, J. E., Law, B.E., Peterson, J.A. \& Tennyson, M.E. 1996. Gas plays of the U.S. Geological Survey 1995 national assessment that underlie regionally extensive surface volcanics. Houston, U.S. Geological Survey, 14p. (Internal report).

Schön, J.H. 2015. Physical properties of rocks: Fundamentals and principles of petrophysics. Amsterdam, Elsevier, 512p.

Schutter, S.R. 2003. Occurrences of hydrocarbons in and around igneous rocks. Geological Society London Special Publications, 214(1): 
35-68.

Seubert, B.W. 2015. Volcaniclastic Petroleum Systems - Theory and Examples from Indonesia. In: $39^{\text {th }}$ ANNUAL CONVENTION \& EXHIBITION, 2015, Montana. Anais...Montana, AAPG, IPA15-G-026.

Senger, K., Millett, J., Planke, S., Ogata, K., Eide, C. H., Festøy, M., Galland, O. \& Jerram, D.A. 2017. Effects of igneous intrusions on the petroleum system: a review. First Break, 35(6): 47-56.

Sharipov, Z. 2018. Productive reservoirs discovery in basement bocks using geophysical and geological data. In: SPE ANNUAL CASPIAN TECHNICAL CONFERENCE AND EXHIBITION, 2018, Astana. Anais...Astana, SPE, p. 21.

Spacapan, J.B., Palma, O., Rocha, E., Leanza, H.A., D'Odorico, A., Rojas Vera, E., Manceda, R., Medialdea, A. \& Cattaneo, D.M. 2018. Maturation of the Vaca Muerta and Agrio formations caused by the location of a magmatic intrusive complex in the southern sector of the Neuquén Basin. Revista de la Asociacion Geologica Argentina, 75(2): 199209.

Spacapan, J.B., D'Odorico, A., Palma, O., Galland, O., Rojas Vera, E., Ruiz, R., Leanza, H.A., Medialdea, A. \& Manceda, R. 2020. Igneous petroleum systems in the Malargüe fold and thrust belt, Río Grande Valley area, Neuquén Basin, Argentina. Marine and Petroleum Geology, 111: 309-331.

Souza-Lima, W., de Carvalho Pinho, G., Silva, P.M. \& Paraizo, P.L.B. 2006. Classification of igneous rocks into electrical profiles. Boletim de Geociências da Petrobras, 14(1): 185-191.

Sruoga, P. \& Rubinstein, N. 2007. Processes controlling porosity and permeability in volcanic reservoirs from the Austral and Neuquén basins, Argentina. AAPG Bulletin, 91(1): 115-129.

Sun, H., Zhong, D. \& Zhan, W. 2019. Reservoir characteristics in the Cretaceous volcanic rocks of Songliao Basin, China: A case of dynamics and evolution of the volcanoporosity and diagenesis. Energy Exploration \& Exploitation, 37(2), 607-625.

Sun, H. \& Zhong, D. 2018. Origin and forming process of the porosity in volcanic hydrocarbon reservoirs of China. Journal of Volcanology and Geothermal Research, 350: 61-68.

Tan, M.T., Ha, M.T., Marfurt, K.J., Hieu, N.T. \& Hanh, N.T.M. 2016. Enhancement of seismic data processing and interpretation of fracture zones on the upper part of granitic basement in Cuu Long basin, Vietnam. Acta Geophysica, 64(6): 2214-2231.

Thomaz Filho, A., Mizusaki, A.M.P. \& Antonioli, L. 2008. Magmatism in Brazilian sedimentary basins and its influence on oil geology. Revista Brasileira de Geociências, 38: 128-137.

Tigre, C.A., Schaller, H., Del Lucchese JR. \& Possato, S., 1983. Pampo, Linguado, and Badejo fields: their discoveries, appraisals, and early production systems. In: OFFSHORE TECHNOLOGY CONFERENCE, 1983, Houston. Anais...Houston, OTC.

Trice, R., Hiorth, C.\&Holdsworth, R. 2019. Fractured basement play development on the UK and Norwegian rifted margins. Geological Society London Special Publications, 495(2018).

Venara, L., Chambi, G.B., Cremonini, A. \& Limeres, M. 2009. Estancia dos Lagunas: producing gas and condensate from a volcanic rock in the Argentinean Austral Basin. In: 24th WORLD GAS CONFERENCE, 2009, Buenos Aires. Anais...Buenos Aires, IGU, v. 1, p. 5-9.

Wang, P. \& Chen, S. 2015. Cretaceous volcanic reservoirs and their exploration in the Songliao Basin, northeast China - Volcanic Reservoirs and Their Exploration. AAPG Bulletin, 99(3): 499-523.

Wang, Y., Yang, R., Song, M., Lenhardt, N., Wang, X., Zhang, X., Yang, S., Wang, J. \& Haifang, C. 2018. Characteristics, controls and geological models of hydrocarbon accumulation in the Carboniferous volcanic reservoirs of the Chunfeng Oilfield, Junggar Basin, northwestern China. Marine and Petroleum Geology, 94: 6579.

Withers, R., Eggers, D., Fox, T. \& Crebs, T. 1994. A case study of integrated hydrocarbon exploration through basalt. Geophysics, 59(11): 1666-1679.

Xiaohong, L., Mingyou. F., Aihua, X. \& Chang, L. 2016. Fractures Types of Volcanic Reservoir and its Significance to Reservoir in the Dixi Area of the Kelameili Gas Field, Junggar Basin, Northwestern China. In: PROCEEDINGS OF 
AAPG ASIA PACIFIC GTW, 2016, Bangkok. Anais...Bangkok, AAPG.

Yao, W., Chen, Z., Hu, T., Liang, Z., Jia, C., Wu, K. \& Dang, Y. 2020. Storage space, pore structure, and primary control of igneous rock reservoirs in Chepaizi Bulge, Junggar Basin, western China: Significance for oil accumulation. Journal of Petroleum Science and Engineering, 195: 107836.

Zahedi, M.K. \& MacDonald, S. 2018. Volcanics: A Commonly underestimated part of Petroleum Exploration. In: $1^{\text {st }}$ AUSTRALASIAN EXPLORATION GEOSCIENCE CONFERENCE, 2018, Sydney. Anais...Sydney, ASEG, p. 1-6.

Zakharova, N.V., Goldberg, D.S., Sullivan, E.C., Herron, M.M. \& Grau, J.A. 2012. Petrophysical and geochemical properties of Columbia River flood basalt: implications for carbon sequestration. Geochemistry, Geophysics, Geosystems, 13: Q11001.

Zou, C. 2013. Volcanic reservoirs in petroleum exploration. Amsterdam, Elsevier. 204 p.

Zou, C. 2017. Unconventional petroleum geology. Amsterdam, Elsevier. 494 p. 